\title{
International Experience in Staff Management in the Process of Staff Recruitment for Vacant Positions with the Application of Social Networks in the Conditions of Digitalisation
}

\author{
Natalita Klietsova \\ Faculty of Law, Department of International Relations, \\ Sumy National Agrarian University \\ LIUBOV MYKHAILOVA \\ Faculty of Management, Department of Management, \\ Sumy National Agrarian University
}




\begin{abstract}
The article researches the international practice of human resources management in the context of digitalisation. The method of expert assessments and analytical methods are used. The basic advantages of finding employees for vacant positions in social networks are revealed, which allowed the authors to propose the algorithm of an HR manager's staff recruitment for an enterprise's vacant position in social networks. In contrast to existing approaches, this methodology involves five basic steps. The usage of this algorithm will enable HR managers and executives to avoid the stage of work with staff agencies, will reduce the enterprise's costs on staff recruitment for the vacant position, will form a staff reserve and, at the same time, will make the process of staff recruitment mobile in conditions of digital economy.
\end{abstract}

Keywords: international staff management, digitalisation, staff recruitment for the position, HR manager, social network, recruiter, enterprise, algorithm, employment

JEL Classification Codes: M54; J53; J23; F02; D41

\title{
Introduction
}

Global digitalisation of management processes in enterprises is accompanied by a change in hierarchical principles of management and a rigid system of administrative influence to create a new organisational culture. At the same time, both management theorists and practitioners refer to the rapid transformation processes in the field of human resource management in society and in the staff management system of enterprises. First of all, such processes began to manifest themselves in international companies, or in enterprises with foreign capital, or those working in open economies (Mykhailov et al., 2020). Owners of modern businesses, which are characterised by mobility, know that there is a direct link between the company's profits, effective management tools, skilled workers and the method of selection for the position of such an employee. However, it is known that in the international environment there are a large number of laws regulating various stages of employment. Therefore, at the initial stage of formation of a vacant position at the enterprise, staff audit is relevant. For example, enterprises of such developed countries as the USA, Switzerland, Canada, Germany, and Austria regularly conduct staff audits. And this, in turn, helps to identify problems that hinder compliance with existing labour laws, the employee's compliance with a given position, the avoidance of lawsuits or fines by government agencies. After monitoring the company, the governing body is able to generate a request for a vacant position. At the same time, in order to carry out a rational selection of the staff in the organisation, business leaders understand 
that the availability and possession of existing methods is only $50 \%$ of success. The rest $50 \%$ remains on the side of the modernity and adaptability of such methods to today's requirements of the business environment, especially taking into account the digitalisation of the economy.

Thus, researching the transformation of the staff management system in international companies, including the algorithm for selecting employees for a vacant position, scientists I.V. Khadzhinov (Khadzhinov, 2018) and M. Ye Shkurat (Shkurat, 2018) emphasise that today more and more employers are looking for employees with new skills to maintain the competitive advantage of their enterprises and increase labour productivity. The emphasis on creative skills is already made during the formation of requirements for candidates for vacant positions, and thus the new generation of employees is aware of their own rapidly growing opportunities in new jobs. Accordingly, there is a pattern that other employees feel how quickly the prospects in the list of their profession, which until recently was traditionally considered a stepping stone to building a career, are disappearing. And as the World Economic Forum Future of Jobs Survey 2018 (Till et al., 2018) was about certain disappearing professions, then we can talk about new priority competencies of the employee. And here is a new set of digital businesses for businesses, and for employees - extraordinary, new digital work skills. We share the opinion of the abovementioned scholars on the approach to building the algorithm of a candidate for a vacant position, and we believe that modern employee competencies related to the digitalisation of the economy are an integral indicator of the company's positioning in a competitive environment.

Moreover, such foreign researchers and practitioners as D. Blasingame (Blasingame et al., 2015), A. Ghosh (Ghosh et al., 2015), M. Isaacson (Isaacson et al., 2015), D. Conrad (Conrad et al., 2015), K. O'Hara (O'Hara, 2017), S. Certo (Certo et al., 2012), T. Certo (Certo et al., 2012) make a strong emphasis on the fact that society is transforming very quickly, and therefore, business processes must accelerate. The time to find new employees offline is secondary, and the challenges of globalisation and the pandemic will see a reassessment of strategic goals. In particular, we mean here such forms of manifestation of the peculiarities of the impact of globalisation challenges as: increasing labour migration in the world; emergence of new professions and activities, including IT, automation, robotics; environmental threats; military conflicts, pandemics, etc. It is worth noting that this field of questions remains really little studied by Ukrainian scientists, although the practice of functioning enterprises proves that the digitalisation of the economy reduces the time spent on commuting, meeting with partners as well as the awareness of what is happening in the business environment. 
However, the practical experience of functioning domestic enterprises proves that any assumptions and research of both scientists and practitioners need a thorough rethinking and adaptation to the modern digital environment. The transformation of technologies of international experience of staff management under the influence of digital economy is significantly accelerated, which, accordingly, requires a thorough study, systematisation of approaches to recruiting for vacant positions in the application of digital HR in domestic enterprises based on international experience. Thus, the purpose of this study is to build an alternative algorithm for a searching HR manager to find a prospective employee for a vacancy with the use of social networks, taking into account the international experience of digitalisation of the economy Consequently, analysing the above-mentioned, we can stress that the chosen research topic is current and relevant.

\section{Research methodology}

The methodological basis of this article is a set of methods and techniques of scientific knowledge. A systemic approach was used as a general scientific method, which allowed us to identify problematic issues related to human resource management in the context of globalisation challenges. In particular, we discuss here modern forms of manifestation of the peculiarities of the impact of globalisation challenges associated with labour migration at the macro and micro levels, the emergence of new IT professions, robotics, pandemics, and so on.

Moreover, thanks to the method of system analysis, we have proposed a common algorithm for selecting employees for a vacant position. The method of expert analysis gave us the opportunity to form the main reasons that stand behind the employer refusal to employ the person for a vacant position, as well as to obtain information for further construction of the search algorithm for an HR manager looking for an employee for a vacant position in social networks. Thus, in order to search for candidates for the vacant position as professionally as it is possible, the challenges of the modern business environment were taken into account, as well as the logical-heuristic method was used, in particular, the method of expert assessments. The study was based on a series of seminars titled Pitfalls in the business of the entrepreneur, held annually by the "Zevs"Audit Firm. We conducted our research during the period of 2012-2019. To speed up the survey process, we developed questionnaires in three languages: Ukrainian, Russian, and English. The content of the questionnaire was formed on the basis of the theoretical analysis of research conducted in this area, as well as taking into account the authors' own vision of this issue. The respondents were asked to give the expert assessment of the problem 
directly related to human resource management in various sectors of the Ukrainian economy and the possibility of implementing foreign experience to improve business processes. The biggest number of questions was constructed in such a way that the respondents had an opportunity to express their own opinion on the problems in the most differentiated way - some of the proposed answers to the questions had four or more gradations. At the same time, a vast majority of questions allowed for the usage of several answer options. Initially, the primary data of the questionnaire were calculated and the assessments of the respondents on individual items of the questionnaire were compared. Then, some identified factors were used as groups of indicators to quantify the views expressed by the interviewed audience. And based on the quantitative assessment of human resource management, we provided the qualitative description of the research issues. Particular attention was paid to the selection of staff for vacant positions with the use of digitalisation. An important indicator of the expert survey is that the sample of the respondents consisted of 675 people, of whom $23 \%$ were representatives of other countries. It should be noted that $64 \%$ of the respondents were business owners, $36 \%$ - hired highly qualified managers with experience in this field for more than 10 years. Among the respondents, almost $58 \%$ were male and $42 \%$ were female. Special attention should be paid to the age category of the respondents, as the age of the respondents also varied, a vast majority of the respondents were aged $30-38$ years old (76\%), the rest 39-49 years old (17\%), and 50 years old and even older (6\%).

The comparative method was used in the process of analysing the benefits of finding employees for vacant positions in social networks. By means of the logical semantic method, the necessity of fixing the searching algorithm of the applicant for a vacant position in social networks by the HR manager was formed.

\section{Results of the main research material}

The pandemic is a crisis factor for which no country has been sufficiently prepared. Emergency health precautions have been actions that have restricted many people's access to work, leading to reduced or even no earnings (Klietsova et al., 2020). COVID-19 also had a significant impact on the process of transformation of the human resources management system in enterprises, including the dismissal of the staff, emergency search for new staff, and more. And today, when researching the selection of staff for a specific position in the enterprise, a vast majority of scientists discuss a certain sequence or the so-called algorithm, which should be followed by managers, HR managers, or recruiters. In particular, such scientists as O.B. Danchenko, V.O. Zanora, Yu.M. Kuzminskaya, L.S. Chernova (Zanora et al., 2013), M.V. Chorna, 
M.M. Bilonozhko (Chorna et al., 2013), A.V. Sogryna, T.M. Chernova (Sohryna et al., 2010), having carried out a thorough analysis of scientific works of domestic scientists who pay attention to the issue of staff selection, came to the conclusion that today there is no clear understanding what the recruitment procedure for Ukrainian companies should look like in order to avoid the influence of subjectivity in the selection process. And we agree with the opinion of these scientists, because, as a rule, in the works of domestic researchers of scientific and practical nature there are mentioned only well-known methods of selection of employees, the procedure for their selection presented in the conventional form (Figure 1). And only $5 \%$ of works contain a description of formalised methods and techniques.

Figure 1. The generally accepted algorithm for selecting employees for a vacant position

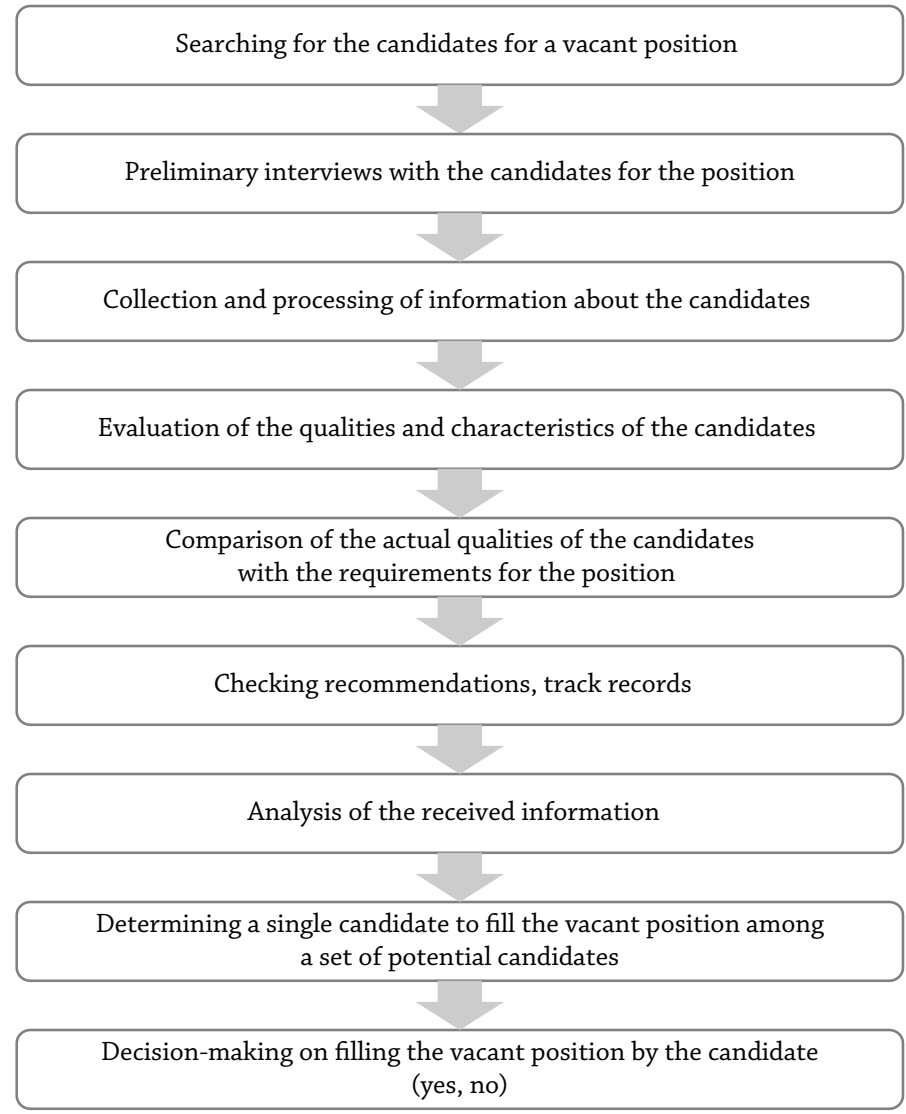

Source: own work on the basis of Zanora et al. (2013), Chorna et al. (2013), Sohryna et al. (2010). 
Thus, in Figure 1 it can be seen that in enterprises there is an initial selection of candidates in terms of technical and functional skills, as such skills really influence the final decision of acceptance of the candidate for a position. According to this algorithm, we can also say that recruitment specialists check each candidate for compliance only to make sure that their chosen candidate is ideal in accordance with the paperwork, and as it turns out, the employee treats colleagues badly and in general is very unpleasant in communication.

However, the practice proves that vacancy announcements with long lists of skills are meaningless. A person who fully meets the requirements can be a terrible worker, and vice versa - a person who meets the requirements of only $20 \%$ will be able to perform the tasks perfectly well.

Moreover, research conducted by Harvard psychologists has shown that success in career growth in $85 \%$ does not depend on a person's level of training, but on his or her individual qualities (Sohryna et al., 2010). At the same time, L. Mykhailova emphasises human capital, we mean the capital accumulated by a person due to his or her innate (physical and intellectual) abilities and talents, which are developed by furthering one's education, qualifications, acquisition of knowledge, skills and competencies, which can provide returns. The higher the human capital, expressed in the level of education, qualifications, knowledge, experience, the greater the human potential for productive high-quality work (Mykhailova, 2020). Such results provide a person with greater remuneration at work, higher status, and opportunities to be accepted for a vacant position.

The example of Nigeria (IBRD, 2016) can serve as an international practice of staff management in the selection of vacancies and ways to create new vacancies, in particular, when the Nigerian government decided to remove ghost workers from employment in the civil service. The situation was resolved through an audit and with the help of the World Bank. The methodology included questionnaires, physical accounting, preparation of general nominal lists (staff register), scanned photographs and the use of file numbers to search for relevant people, compilation of actual staff costs and calculation of personnel costs based on the number of accounts reflected in the nominal list. And this saved a fairly large amount of money. Thus, the systematic conduct of staff audits has helped business owners save thousands of dollars each year. And today, in the context of digitalisation of the economy, regular audits in the field of staff management in the enterprise can help companies maintain a competitive advantage, avoid potential losses, and improve human capital management (Bieliaieva, 2019). It should be understood that the field of human resources (HR) has developed in recent years so much that all universities in South Africa now offer staff qualifications, to provide one instance. However, in our previous studies (Klietsova et al., 2017), it was proved that for Ukraine, for example, 
the problem of young graduates' to find their first job is the most essential one at this stage of the country's development as well as during the selection of employees for vacant positions. We can explain the problem described above by the fact that graduates are considered to be the very people that do not have enough experience for the diligent performance of their duties at the enterprise. More of that, there is a dilemma: to employ an experienced, but elderly person or to give a real opportunity for the development and training of young graduate professionals. If internal managers' ego allows them to be risk-taking and to employ a young employee, it means that at such an enterprise there will appear a real chance to start an absolutely new stage of development in the context of digitalisation of the economy.

The question arises why employers seek to establish a huge list of requirements. Why not just conduct interviews, during which you can provide a situational task in the field of a vacant position? During the interview, an attentive listener, in particular a recruiting specialist, can learn a lot of interesting things about a candidate's previous projects. It should be borne in mind that an interview should not be limited to trivial questions such as: "How many years have you used Excel?". This question will not give any idea of what the respondent really knows about this programme. It is also interesting to see the approach when the employer tries to recruit a candidate who could be a talented marketer, but if the name of the vacant position never mentioned the word marketing, the HR manager will never know about it if he or she does not talk to the recruit. That is why the recruitment process should not be limited to a thoughtless search for matches. Moreover, smart workers are quickly introduced to new tools. So, if the company needs good employees, it is advisable to eliminate the conventional methods of interviewing and not to select a resume, using keyword search. Our research at enterprises in some regions of the NorthEastern Region of Ukraine has identified five main reasons why it is not advisable to hire employees even if they perfectly meet the requirements of the list of candidates for a given vacant position (Figure 2).

The reasons we have identified must have a basis. For example, if a candidate ignores an agreement to get in touch for weeks, it means that this person has other offers. And why employ a person who will always strive to work in another company? If an HR manager wants to hire smart and interested employees, staff should remember that curiosity is a very valuable quality. In this case the prospective candidate for the vacant position should always have definite questions to the HR manager.

When discussing rudeness, we do not mean awkward situations that can happen to anyone. We mean those applicants who come to the interview and behave defiantly. Recruiters, HR managers can interpret this situation as follows: in a previous job, this person was treated unfairly. It is advisable to employ this candidate and treat this person better than the previous employer, and the applicant will appreciate it. 
According to $84 \%$ of the respondents, in three or four months such an employee will be fired, and other team members will have to overcome the stress caused by their presence for a long time. We believe that if a candidate for a vacant position shows aggression at the initial stage of the recruitment process, it is not advisable to employ this person, even if this employee has exceptional technical abilities. The main resource of the employer is the team, and nobody could be allowed to destroy it.

Figure 2. The main reasons that stand behind the refusal of the employee to employ him or her for a vacant position

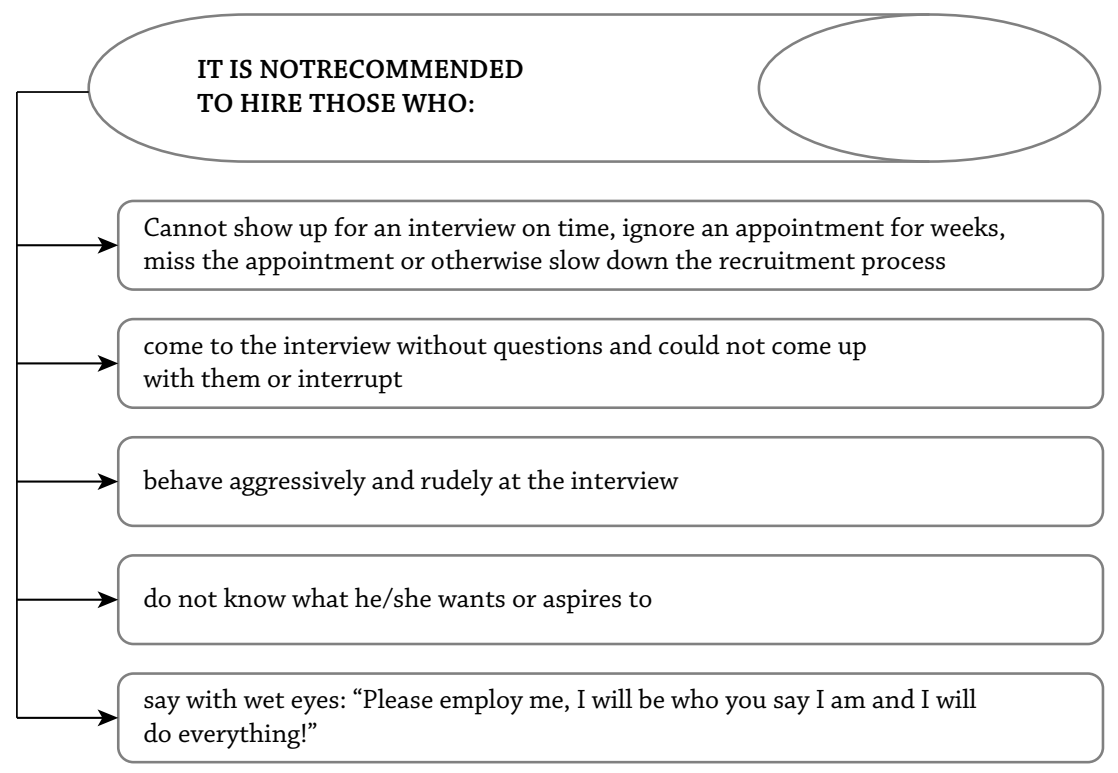

Source: own research, based on an expert survey conducted at a series of seminars Pitfalls in the business of the entrepreneur in 2017 (the respondents: 295 people: managers, HR managers, recruiters of Sumy, Kharkiv and Poltava Regions, Ukraine).

If a candidate does not know what he/she wants or aspires to, you should not even waste time for a job interview. An adult should be guided by the principle: "Where do I want to be?" and "Why do I want to learn?". Speaking about the pity for the prospective employee, any HR manager should be aware that skilled employees have a healthy self-esteem. And if the interlocutor does not know his or her value, this person will not be able to complement the team of the company, nor bring a positive spirit for its future ideas.

Given the results of our research at the seminars Pitfalls in the business of the entrepreneur, and considering the views expressed by young business leaders (age category up to 38 years), we believe that today there is a need for urgent monitoring 
of applicants for vacant positions in social networks. Indeed, social networks in the selection of staff is quite a new, but relevant tool. For example, HR managers of functioning agricultural enterprises of Sumy and Kharkiv Regions use this tool in 16\% of cases, it means far from fully. The reason for the rejection of social networks as a tool for selecting employees for a vacant position is access to a list of other verified employment sites. In some organisations, access to social networks is completely closed. In order to understand the relevance of social networks in today's digital business environment, we defined the benefits provided by this tool (Figure 3).

Figure 3. Advantages of finding employees for vacant positions in social networks

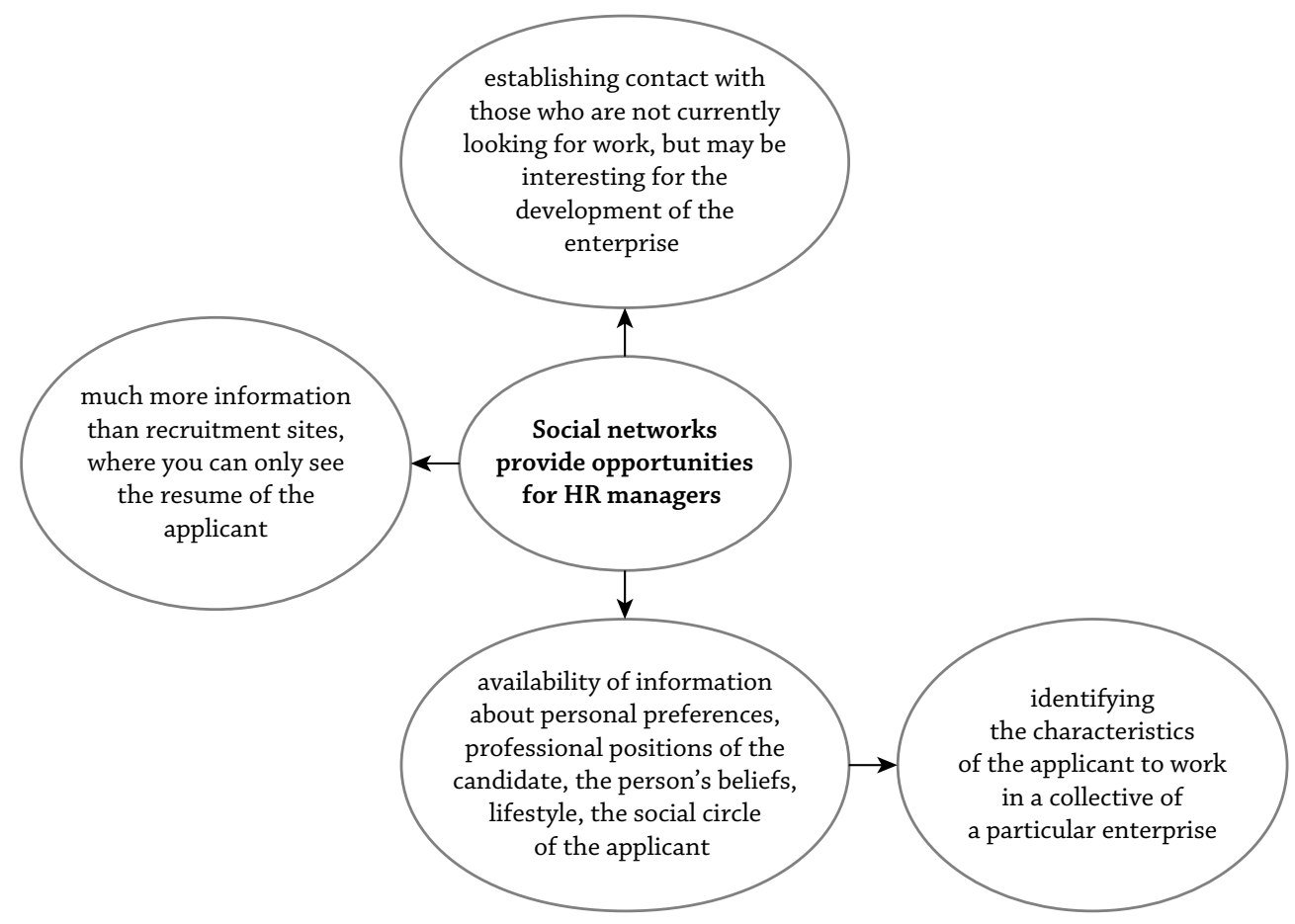

Source: own research.

Obviously, social networks will not replace traditional job search sites, but it would be unwise to abandon them. Firstly, social networks provide HR specialists with much more information than recruitment sites, where HR managers can only see the resumes of candidates for vacant positions (O'Hara, 2017). Secondly, social networks contain information about the personal preferences and professional positions of the candidate, this person's beliefs, lifestyle, and social circle. In this way, HR managers will be able to find out how well the chosen person will fit into 
the work team and whether he will become part of the company's team or not. At the same time, thanks to social networks, the recruitment manager can establish contact not only with those applicants who are looking for work, but also with those who are not currently looking for it at all but can be really interesting for the development of the organisation. Thus, it can be seen that the use of social networks in the recruitment of employees has both short-term and long-term goals.

However, even using this recruitment tool it should be borne in mind that there is currently no one-size-fits-all network for finding employees of all professions. That is why it is important to understand the specifics of each of them. We can say that Facebook is one of the widest networks. It is suitable for finding line specialists and middle managers (Blasingame, 2015; Conrad et al., 2015). Facebook has a huge number of professional communities, but due to the fact that the network was created and positioned as a tool for communicating with friends, the job search process is not a priority for registered users, while Linkedin is a network for making professional contacts. In it you can find both line specialists and top managers. Professionali. $\mathrm{ru}$ is a Russian analogue of the Linkedin network. With its help, one can look for specialists in various fields, and a vast majority of them have experience in big Russian companies. In our opinion, in the conditions of mobility of the business environment there is no need to work with all these social networks. It will be enough for HR managers to choose only two or three of them. Their choice depends on who they will need to find and for what vacancy. According to the respondents, we also found that $31 \%$ of HR managers recommend using blogs and microblogs to find employees, such as: livejournal.com, blogspot.com, twitter, chikchirik, etc. Their main advantage is that the activity of a blogger outside their own blog is easily tracked by search engines such as Google, Yahoo, etc.

Taking into account that the procedure for finding a candidate for a vacant position in social networks requires a certain algorithm, we propose depicting it as shown in Figure 4. In order for the selection for a vacant position to be effective, first of all it is necessary to use the existing profile of the HR manager, in which it is advisable to indicate as much personal information as possible. In addition, there should be a wide base of friends among colleagues, classmates, and acquaintances to analyse the virtual social activity of the candidate for the vacant position, as well as its uniqueness. The next step is the process of forming virtual opponents for the HR manager through discussions in professional communities. An integral part of this stage is the formation of a circle of associates among the friends of the HR manager who position themselves as professionals in the same industry with the HR manager. In this case, the greater the number of such friends in the HR manager's circle, the higher his or her status in the social network. 
Within the social networks of the HR manager, it is necessary to use groups and communities which include people interested in the HR manager. In this case, the HR manager should make sure: 1 ) whether the group and its members meet the vacant position of the company where the supposed candidate works; 2) how often the content in this group is updated; 3 ) how active this group is. Practice has shown that it is better to start meeting an HR manager in the process of joint discussion of professional issues.

For the effective search for employees in social networks it is not enough to create just an account. The profile of the HR manager should be filled with personal data as much as possible, moreover, this HR manager should be constantly active in professional communities, the page of the HR manager should have unique publications.

\section{Figure 4. The algorithm of searching the candidate for a vacant position in social networks by the HR manager}

Stage 1. Using the existing profile of the HR manager and this person's base of friends to analyse the virtual social activity of the candidate for the vacant position, as well as its uniqueness.

Stage 2. Formation of virtual opponents for the HR manager through discussions in professional communities; forming a circle of associates among the friends of the HR manager, who position themselves as professionals of the same industry with the HR manager.

Stage 3. Monitoring groups and communities which include persons interested in the HR manager. Make sure: 1) whether the group and its members correspond to the vacant position of the company where the HR manager works; 2) how often the content in this group is updated; 3 ) how active this group is.

Stage 4. Maximum filling in of the HR manager's profile with personal data, support of this person's constant activity in professional communities, availability of unique publications on the HR manager's page.

Stage 5. Support of a good social network platform (stable circle of friends and active profile page).

Source: own research. 
Uniqueness should be understood as one's own opinion, view, or impression on a specific problem, indicating the interest in the field of professional orientation of the HR manager. The final stage of effective recruitment using social networks is that there should be a continuous process of maintaining a good social network platform, in particular, a stable circle of friends and an active profile page. Thus, the usage of social networks will provide an opportunity to change radically the existing process of selection of employees for the vacant position.

\section{Conclusion}

Thus, our research allows us to conclude that in today's conditions of digital business environment, the generally accepted algorithm for selecting employees for vacant positions in enterprises should be adapted to the current conditions of organisations. The advantages of searching for employees for vacant positions in social networks revealed by us allowed us to offer the algorithm for searching for candidates for a vacant position in social networks by HR managers. Unlike existing algorithms, the application of this algorithm will allow the HR manager and the head of the organisation to avoid the stage of working with recruitment agencies, reduce the company's costs for recruiting for a vacant position, will form a reserve and, at the same time, make the selection process mobile.

\section{References}

Bieliaieva, N.S. (2019). Mizhnarodna praktyka provadzhennia kadrovoho audytu. Efektyvna ekonomika, 12. Retrieved from: http://www.economy.nayka.com.ua/ pdf/12_2019/70.pdf (accessed: 19.1.2021).

Blasingame, J. (2015, Aug 7). Motivating Employees Is Good Business. Forbes,. Retrieved from: http://www.forbes.com/sites/jimblasingame/2015/08/07/motivatingemployees-is-good-business/\#3f4a847d1bb1 (accessed: 22.1.2020).

Certo, S.C., \& Certo, S.T. (2012). Modern management: concepts and skills. New Jersey: Prentice-Hall, Upper Saddle River, $12^{\text {th }}$ ed. Retrieved from: https://jakanugraha. files.wordpress.com/2015/08/modern-management-12e.pdf (accessed: 24.12.2019).

Chorna, M.V., \& Bilonozhko, M.M. (2013). Pidbir personalu na pidpryiemstvi: systemnyi ta protsesnyi pidkhody. Ekonomichna stratehiia i perspektyvy rozvytku sfery torhivli ta posluh, 1(2), 69-76.

Conrad, D., Ghosh, A., \& Isaacson, M. (2015). Employee motivation factors: A comparative study of the perceptions between physicians and physician leaders. International Journal of Public Leadership, 11(2), 92-106. 
International Bank for Reconstruction and Development (2016). Digital Dividends. A World Bank Group Flagship Report. Retrieved from: http://documents1.worldbank. org/curated/en/896971468194972881/pdf/102725-PUB-Replacement-PUBLIC. pdf (accessed: 20.2.2021).

Khadzhinov, I.V., \& Shkurat, M. Ye. (2018). Transformatsiia systemy menedzhmentu personalu mizhnarodnykh kompanii. Problemy systemnoho pidkhodu v ekonomitsi, 6, 33-40. Retrieved from: https://r.donnu.edu.ua/bitstream/123456789/863/1/\%D0\%A8\%D0\%BA\%D1\%83\%D1\%80\%D0\%B0\%D1\%82\%2006.pdf (accessed: 27.12.2020).

Klietsova, N., \& Shyshlevska, P. (2020). Research on human rights to work in the worldwide COVID-19 conditions: comparison of international experience. Visegrad Journal on Human Rights, 2(1), 121-126. Retrieved from: http://vjhr.sk/archive/2020_2/ part_1/20.pdf (accessed: 5.2.2021).

Klietsova, N., \& Volchenko, N. (2017). Employment Policy in the Context of European Integration of Ukraine. Finance and Management Journal of the Faculty of Economic Sciences, University of Warmia and Mazury in Olsztyn. Poland, 2(1), 41-51. Retrieved from: http://www.uwm.edu.pl/wne/podstrony/fm/files/FMJ_2017_v2n2.pdf (accessed: 27.1.2021).

Mykhailov, A., Mykhailova, L., Kyrychenko, T., Haiyan, Yin, \& Zhiping, Huo (2020). Innovative Approaches in the Management of Human Capital Development in the Context of Rural Population's Life Quality Improvement. International Journal for Quality Research, 14(4), 99-108. Retrieved from: http://www.ijqr.net/archive. php? $=14 \& \mathrm{n}=4 \& \mathrm{y}=2020$ (accessed: 1.9 .2020 ).

Mykhailova, L.I. (2020). Upravlinnia rozvytkom liudskoho kapitalu v konteksti pidvyshchennia yakosti zhyttia silskoho naselennia. Ekonomika APK, 5, 66-76. Retrieved from: http://www.eapk.org.ua/contents/2020/05/66 (accessed: 17.2.2021). O'Hara, C. (2017, Jan 3). How to Get an Employee to Work Faster. Harvard Business Review. Retrieved from: https://hbr.org/2017/01/how-to-get-an-employee-to-workfaster (accessed: 12.2.2020).

Sohryna, A.V., \& Chernova, T.M. (2010). Osobennosty sovremennukh netradytsyonnykh metodov otbora personala. Vestnyk Volhohradskoho hosudarstvennoho unyversyteta. Seryia 9: Yssledovanyia molodykh uchenykh, 8(2), 84-89.

Till, A.L., Vesselina, S.R., \& Saadia, Z. (2018). The Future of Jobs Report. World Economic Forum. Centre for the New Economy and Society, 147. Retrieved from: http://www3. weforum.org/docs/WEF_Future_of_Jobs_2018.pdf (accessed: 4.2.2021).

Zanora, V.O., Chernova, L.S., Kuzminska, Yu.M., \& Danchenko, O.B. (2013). Metodyka pidboru kadriv z vrakhuvanniam orhanizatsiinykh ryzykiv. Upravlinnia proektamy ta rozvytok vyrobnytstva: Zb.nauk.pr. Luhansk: vyd-vo SNU im. V. Dalia, 1(45), 88-94. 


\section{Nataliia Klietsova}

$\mathrm{PhD}$ in the discipline of enterprise management, Associate Professor at the Faculty of Law of Sumy National Agrarian University in the Department of International Relations, doctoral student in Management, a certified auditor in "Zevs" Audit Firm, Sumy, Ukraine. Her research interests focus on international human resources management, implementation of international employment practices to Ukrainian enterprises, legalisation of labour relations both at enterprises and in the country as a whole in terms of digitalisation of the economy. She was a tutor of the Erasmus+ international project, the Ukrainian-Polish project within the programme of the Polish-Ukrainian Council of Youth Exchange, funded by the Ministry of Education of Poland. She has made institutional visits to the European Court of Human Rights and the Council of Europe (2018); Reichstag, International Court of Justice, International Criminal Court (2019). She is the Laureate of the Verkhovna Rada of Ukraine for the Most Talented Young Scientist in the Field of Basic and Applied Research and Scientific and Technical Development. She is the author of over 100 scientific papers, and a member of the "Center for UkrainianEuropean Scientific Cooperation" scientific organisation.

e-mail: klietsovanataliia@gmail.com

ORCID: 0000-0003-4910-8912

\section{Liubov Mykhailova}

Doctor of Economic Sciences, Professor at the Management Department, Sumy National Agrarian University, Sumy, Ukraine. Honoured Worker of Education of Ukraine; leading scientist of the Department of Agrarian Economics and Food of the National Academy of Agrarian Sciences of Ukraine; Honorary Professor of Kharkiv National Agrarian University named after V.V. Dokuchaev. She is the Member of the editorial boards of scientific journals: Economics of AIC, Economics and Management Sumy National Agrarian University series, Bulletin of Kharkiv National Agrarian University, Tourism and Regional Development Faculty of Economics, Warsaw University of Life Sciences series. Her main research interests are: human capital management in rural areas; leadership and HR management; development of foreign economic and innovative activity in the agricultural sector of the country in the conditions of integration and globalisation processes. She has repeatedly received Grants from the Government of Germany and DAAD for research projects and internships in Germany (Halle-Wittenberg University (Halle); 
Weinstefan University of Applied Sciences, (Trisdorf); Institute for Agrarian Development, Central and Eastern Europe (IAMO, Galle). She is the author of more than 300 scientific articles, 30 monographs, 20 textbooks. For a long time she was the chairman of the specialised scientific council for the defence of doctoral dissertations, now - the deputy chairman, the guarantor of the educational programme on $\mathrm{PhD}$ preparation in the Management specialty (JEL Classification Code: 073). She was the head and scientific consultant for the training of $19 \mathrm{PhD}$ candidates and 5 Doctors of Sciences.

e-mail: liubov.mykhailova@snau.edu.ua

ORCID: 0000-0003-2628-5094

Scopus ID: 57203587563 